latiore; antennis pedibusque testaceis, illis apice fuscis, capite paulo longioribus; thorace capite paulo longiore; abdomine elliptico, thorace latiore et paulo longiore; alis subfuscis.-Long. corp. $1 \frac{2}{3}$, alar. $2 \frac{1}{2}$ lin.

Inhabits Madeira proper, principally at intermediate altitudes ;

-Santa Anna, Ribeiro Frio, \&c.

\title{
Bethylus tenuis.
}

B. mas niger; capite oblongo, parce punctato, thorace vix latiore sed multo breviore; antennis testaceis, apice fuscis, capite longioribus; abdomine longi-elliptico, thorace latiore et paulo longiore; pedibus testaceis, femoribus partim piceis; alis anticis subrufescentibus.-Long. corp. $1 \frac{1}{4}-1 \frac{1}{3}$, alar. $1 \frac{1}{2}-1 \frac{3}{4}$ lin.

Inhabits the Northern Dezerta, or Ilheo Chầ, on which I captured it abundantly early in June 1850, and at the end of May 1855.

[To be continued.]

III.-Notice of two new species of Brownia, a genus of Oceanic Mollusca. By Arthur Adams, F.L.S.

Hong Kong, Oct. 1, 1857.

ON the 4th of July, steady breeze and fine weather, while crossing the China Sea, I was fortunate enough to take in the towingnet two new species of the genus Brownia of D'Orbigny. The typical species $B$. Cande $i$ is described as "lateraliter carinatocrenulata," and is probably the same as the Echinospira diaphana of Krohn, the Calcarella spinosa of Souleyet, and the Jasonilla M'Leayiana of Macdonald, all of which have the three salient angles of the whorls armed with short spines. In the species here described the whorls are unarmed, being carinated in one and angulated in the other. The forms described by Krohn, Souleyet, D'Orbigny, and Macdonald, may, however, be all distinct, forming a spinose section of the genus. Unfortunately the shells of my two species were found empty, with the exception of a transparent fragment in one individual of $B$, carinata, an examination of which, in conjunction with the form of the shell of these new species, has led me to infer, with M. D'Orbigny, that the animal is a Heteropod belonging to the family Atlantida, and not to the Macgillivrayida, where my brother and myself have placed the genus Calcarella of M. Souleyet. The shells are so perfectly diaphanous, that they are invisible in water, and were only detected by their adhering to the tongue of red bunting of the towing-net. D'Orbigny describes his Brownia as a section of the genus Helicophlegma, which is the same as the Oxygyrus of Benson and the Ladas of Cantraine. 
When dried, one of my specimens shrivelled up and turned brown, in which state it certainly nearly resembled that genus. Krohn has fully described the animal of his Echinospira diaphana in the 'Archiv für Naturgeschichte' for 1855, but I am unable to give any account of his communication. There is a genus of plants called Brownia, but I have no means of ascertaining the priority.

\section{Brownia carinata, A. Adams.}

$\boldsymbol{B}$. testa compressa, discoidea, cartilaginosa, tenui, pellucida, anfractibus vix 3 , carinis tribus acutis prominentibus cingulatis ; spira plano-concava; apertura rhomboidea ; peristomate tenui, acuto, antice valde producto, lateraliter carinato.

$H a b$. China Sea; taken in the towing-net.

\section{Brownia angulata, A. Adams.}

$B$. testa discoidea, ventricosula, cartilaginosa, diaphana, tenui, anfractibus vix 3 , angulis tribus subacutis cingulatis ; spira plano-convexa ; apertura rhomboidea; peristomate tenui, acuto, antice producto, lateraliter angulato.

Hab. China Sea ; taken in the towing-net.

IV.-On Specific Character, Fecundation, and Abnormal Development in Edogonium. By H. J. Carter, Esq., Assistant Surgeon H.C.S. Bombay.

[With a Plate.]

THE object of the following observations is to point out means by which it is hoped the species of $Q E$ dogonium may be better distinguished; to confirm Prof. Pringsheim's discovery of the mode of impregnation in this genus; and to figure and describe an abnormal growth which takes place from the 'resting-spore.'

Having in vain tried to find out the species of Edogonium which I have had under observation, among those which have been already published, whether from the meagreness of the descriptions and illustrations, or from their having actually been undescribed, while other characters than those already noticed have presented themselves to me, which are evidently more valuable for specific distinction, I have been induced not only to describe, but also to name, those which I have been studying; for whether or not described before, those descriptions and names alone will hereafter be found useful which serve for their identification.

The characters to which I allude are sexual, and therefore can 


\section{$2 \mathrm{BHL}$ Biodiversity Heritage Library}

Adams, Arthur. 1858. "III.-Notice of two new species of Brownia, a genus of oceanic Mollusca." The Annals and magazine of natural history; zoology, botany, and geology 1, 28-29.

View This Item Online: https://www.biodiversitylibrary.org/item/19643

Permalink: https://www.biodiversitylibrary.org/partpdf/18340

\section{Holding Institution}

Natural History Museum Library, London

\section{Sponsored by}

Natural History Museum Library, London

\section{Copyright \& Reuse}

Copyright Status: Public domain. The BHL considers that this work is no longer under copyright protection.

This document was created from content at the Biodiversity Heritage Library, the world's largest open access digital library for biodiversity literature and archives. Visit BHL at https://www.biodiversitylibrary.org. 